\title{
Detecting channel morphology change in California's hard- wood rangeland spring ecosystems
}

\author{
BARBARA ALLEN-DIAZ, RANDALL D. JACKSON, JEFFREY S. FEHMI
}

Authors are associate professor and graduate student researchers, Dept. ESPM-ES, 151 Hilgard Hall \#3110, University of California, Berkeley, Calif. 94720. Authors e-mail address is: ballen@nature.berkeley.edu

\section{Abstract}

Permanent channel cross-sectional transects perpendicular to flow were used to estimate changes in spring and resultant creek channel morphology. Three cattle grazing treatments (none, light, and moderate) were applied to 2-5 ha pastures containing a perennial spring and resultant creek cohort for 5 years. Grazing effects on the total change in channel morphology were not detected, nor did our method detect channel morphology change over the 5 year study period. Ungrazed springs and creeks were observed to change more than grazed springs and creeks although these differences were not statistically significant. Observed, but not significant, change over time appears related to rainfall patterns. Permanent channel cross-sections, one of the currently recommended methods for monitoring livestock grazing impacts on stream channels, may not be adequate for detecting channel changes in low-flow spring/creek systems.

Key Words: riparian, creek, stream, livestock, cattle, graxing, cross-section

California's hardwood rangelands and associated annual grasslands provide $75 \%$ of the forage used by the State's range livestock industry (Ewing et al. 1988). Grazing strategies in these areas historically emphasized yearlong grazing but seasonal grazing systems have received gradual acceptance (Bartolome 1984). Some water quality degradation and riparian vegetation loss has been considered an unavoidable aspect of domestic livestock grazing practices (Bartolome 1993).

Several studies have examined livestock grazing effects on riparian system channel morphology (Gunderson 1968, Roath and Krueger 1982, Kauffmann and Krueger 1984, Marlow et al. 1987, Williamson et al. 1992). Buckhouse et al. (1981) reported that moderate grazing effects were not detectable and that highrunoff-event frequency and timing were primarily responsible for changes in channel morphology. Medina and Martin (1988) and Sidle and Sharma (1996) also found no significant grazing effects

\footnotetext{
The authors wish to thank the many UC Range program graduate students for their sampling assistance. The Integrated Hardwood Range Management Program, University of California funded this project.

Manuscript accepted 8 Mar. 1998.
}

Se usaron transectos transversales permanentes, perpendiculares al flujo del agua en canales, para estimar los cambios en el manantial y en la morfologílía del canal del riachuelo resultante. Tres tratamientos de pastura de ganado (nulo, ligero y moderado) fueron aplicados a potreros de $2-5$ ha con manantial y riachuelo resultante, por un periodo de 5 años. No se encontraron efectos de la pastura sobre el cambio total en la morfologílía del canal. De igual forma, nuestro método no detectó cambios en la morfologílía del canal durante el periodo de 5 años de nuestro estudio. $A$ pesar de que no se encontraron diferencias significativas, los manantiales y riachuelos que no estuvieron sometidos al ganado mostraron más cambios que los manantiales y riachuelos con ganado. Los cambios observados a través del tiempo parecen estar relacionados con patrones de lluvia. Transectos transversales en canales permanentes, uno de los métodos actualmente recomendados para el monitoreo de impacto de la ganaderia en canales de riachuelos, puede no ser adecuado para detectar cambios en canales en sistemas de manantiales $y$ riachuelos de flujo ligero.

on channel morphology. Conversely, Myers and Swanson (1992) found specific grazing practices ameliorated slumping stream banks and disturbed aquatic habitat in central Nevada.

We designed this experiment to determine conservative grazing practice effects on channel morphology for low-flow springs and their resultant creeks at Sierra Foothill Research and Extension Center (SFREC), Browns Valley, Calif. It is one component of a larger study examining cattle grazing effects on vegetation, aquatic insects, and water quality (Campbell and Allen-Diaz 1997) of California's hardwood rangeland spring-creek ecosystems.

\section{Study Site}

Owned and managed by the University of California for more than 30 years, Sierra Foothill Research and Extension Center (SFREC) is located on the western slope of the Sierra Nevada foothills in Yuba County, Calif. It covers 2,300 ha of steep to rolling landscape $90-600 \mathrm{~m}$ above sea level. Annual precipitation at SFREC averages $72 \mathrm{~cm} \mathrm{yr}^{-1}$ with maximum and minimum air temperatures in the region ranging from $32.0^{\circ} \mathrm{C}$ in July to $2.2^{\circ} \mathrm{C}$ 
in January. Dominant vegetation is blue oak (Quercus douglasii Hook. \& Am.)/gray pine (Pinus sabiniana Douglas) woodlands and savannas with introduced annual grass and forb understories. Soils in this area are generally shallow and clumped in the Auburn (loamy, oxidic, thermic, ruptic-lithic xerochrepts) and Argonaut (fine, mixed, thermic mollic haploxeralfs) series (Herbert and Begg 1969).

Spring sources are quite small (width $\sim 0.5 \mathrm{~m}$ ) and typically surrounded by rocks or dense vegetation or both. Two main perennial spring-types are evident at SFREC, those flowing on and around bedrock substrates (Type I) and those seeping through the soil at a slope break with surface flow barely and sometimes not at all visible (Type II). Type I springs are usually found along intermittent stream channels which flow only during high volume rainfall events, overrunning the spring altogether. Typical wetland species Paspalum dilatatum Poiret, Verbena spp., rushes, and sedges among others sharply delineate a spring's boundaries which average $3 \mathrm{~m}$ across perpendicular to flow forming ovallike borders. Most of the year, flow is highly reduced so that it is not measurable by classical techniques that employ floatation devices or revolving apparatus. As spring areas transition into creeks, flow remains sub-surface most of the year.

The highly palatable, perennially green spring vegetation makes for intense cattle use. This is especially evident during spring and summer months as upland vegetation dries. Spatially focused utilization creates visually striking effects on the ground. Cattle are seen to sink to their knees in the saturated soil creating a highly undulated surface, rife with pock marks throughout the spring boundaries. These visually assessed impacts motivated this study.

\section{Methods}

Three spring-creek cohorts were selected from each of 3 SFREC watersheds (Campbell, Schubert, and Forbes) for grazing treatment application (Fig. 1). Watersheds were selected for the presence of an undeveloped spring, geographic proximity, and similar management histories. Campbell possesses the highest geographic similarity; all 3 plots are contiguously located on the same slope with roughly $25-35 \%$ overstory cover of blue oak, interior live oak ( $Q$. wislizenii A.DC.), and spicebush (Calycanthus occidentalis Hook. \& Arn.). Schubert is dominated by dense blue oak, interior live oak, and gray pine overstory ( $-50-60 \%$ cover) in contrast with the Forbes watershed which was cleared of all woody vegetation during 1960 s range improvements, and is now dominated by annual grasses.

A completely randomized block design was employed where watersheds served as blocks such that watershed-to-watershed variation was partitioned from error variances. Each spring-creek cohort within a watershed (block) was randomly assigned a grazing treatment; ungrazed (UG), lightly grazed (LG), or moderately grazed (MG). Grazing treatments were applied annually 1992 through 1997. Cattle were placed within $2-5$ ha treatment areas enclosed by 3-wire electrical fence in November, once during the period January through March, and again in May to simulate yearlong grazing practices and to achieve desired mulch levels (see Table 1 for actual use dates). Experienced Sierra Foothill Research and Extension Center annual grassland range managers monitored grazing treatment intensity during each treatment period. Cattle were left on a site until a visually estimated residual

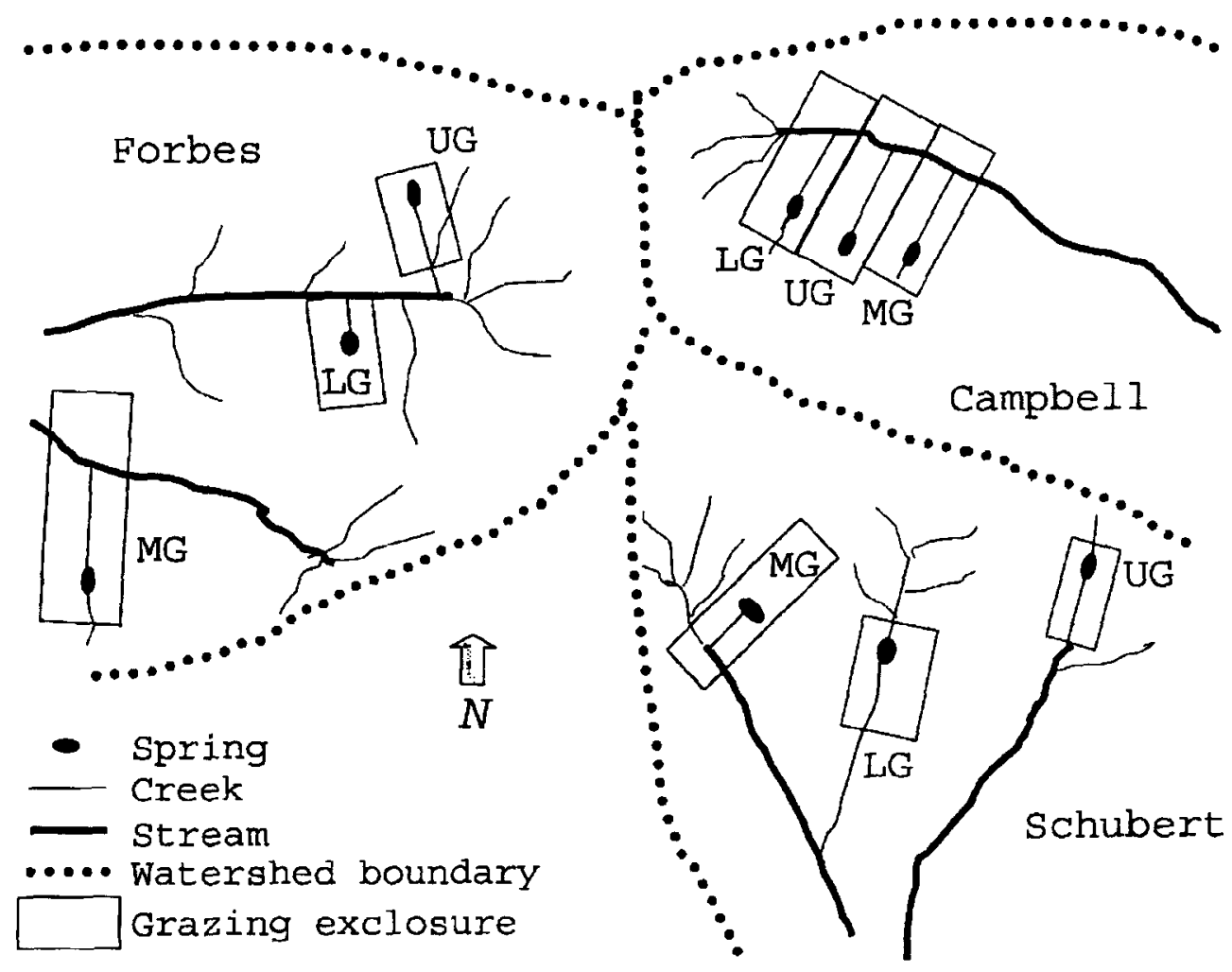

Fig. 1. Sierra Foothill Research and Extension Center experimental design schematic. 
Table. 1 Actual use dates.

\begin{tabular}{|c|c|c|c|c|c|c|}
\hline Year & Watershed & Treatment & On & Off & Head & Days on \\
\hline \multirow[t]{6}{*}{92} & Campbell & LG & 16-Dec & 24-Dec & 6 & 8 \\
\hline & & $\mathbf{M G}$ & 16-Dec & 24-Dec & 4 & 8 \\
\hline & Forbes & $\mathbf{L G}$ & 25-Nov & 15-Dec & 7 & 20 \\
\hline & & MG & 25-Nov & 15-Dec & 3 & 20 \\
\hline & Schubert & LG & 10-Nov & 25-Nov & 5 & 15 \\
\hline & & MG & 10-Nov & 25-Nov & 5 & 15 \\
\hline \multirow[t]{20}{*}{93} & Campbell & $\mathbf{L G}$ & 19-Mar & 26-Mar & 3 & 7 \\
\hline & & & 26-Mar & 1-Apr & 6 & 6 \\
\hline & & & 3-May & 14-May & 3 & 11 \\
\hline & & & 29-Nov & 7-Dec & 4 & 8 \\
\hline & & MG & 19-Mar & 26-Mar & 3 & 7 \\
\hline & & & 3-May & 14-May & 2 & 11 \\
\hline & & & 29-Nov & 7-Dec & 2 & 8 \\
\hline & Forbes & LG & 19-Mar & 1-Apr & 4 & 13 \\
\hline & & & 30-Apr & 14-May & 6 & 14 \\
\hline & & & 14-May & 25-May & 11 & 11 \\
\hline & & & 7-Dec & 13-Dec & 13 & 6 \\
\hline & & MG & 19-Mar & 1-Apr & 4 & 13 \\
\hline & & & 30-Apr & 14-May & 3 & 14 \\
\hline & & & 14-May & 19-May & 6 & 5 \\
\hline & & & 13-Dec & 20-Dec & 7 & 7 \\
\hline & Schubert & $\mathbf{L G}$ & 19-Mar & 1-Apr & 3 & 13 \\
\hline & & & 7-May & 14-May & 3 & 7 \\
\hline & & MG & 19-Mar & 1-Apr & 3 & 13 \\
\hline & & & 7-May & 19-May & 3 & 12 \\
\hline & & & 19-May & 25-May & 6 & 6 \\
\hline \multirow[t]{18}{*}{94} & Campbell & LG & 15-Mar & 24-Mar & 3 & 9 \\
\hline & & & 29-Apr & 9-May & 3 & 10 \\
\hline & & & 1-Dec & 5-Dec & 4 & 4 \\
\hline & & MG & 15-Mar & 24-Mar & 2 & 9 \\
\hline & & & 29-Apr & 9-May & 2 & 10 \\
\hline & & & 1-Dec & 5-Dec & 2 & 4 \\
\hline & Forbes & LG & 24-Mar & 4-Apr & 11 & 11 \\
\hline & & & 9-May & 16-May & 12 & 7 \\
\hline & & & 19-Dec & 27-Dec & 7 & 8 \\
\hline & & MG & 18-Mar & 25-Mar & 6 & 7 \\
\hline & & & 16-May & 31-May & 7 & 15 \\
\hline & & & 26-May & 31-May & 4 & 5 \\
\hline & & & 26-May & 31-May & 4 & 5 \\
\hline & & & 5-Dec & 13-Dec & 6 & 8 \\
\hline & Schubert & $\mathbf{L G}$ & 15-Mar & 24-Mar & 3 & 9 \\
\hline & & & 29-Apr & 9-May & 3 & 10 \\
\hline & & MG & 15-Mar & 24-Mar & 3 & 9 \\
\hline & & & 29-Apr & 9-May & 4 & 10 \\
\hline \multirow[t]{11}{*}{95} & Campbell & LG & 19-May & 2-Jun & 4 & 15 \\
\hline & & MG & 18-May & 2-Jun & 2 & 15 \\
\hline & Forbes & $\mathbf{L G}$ & 2-Mar & 9-Mar & 9 & 7 \\
\hline & & & 18-May & 2-Jun & 10 & 15 \\
\hline & & MG & 24-Feb & 2-Mar & 9 & 6 \\
\hline & & & 30-Apr & 2-May & 3 & 2 \\
\hline & & & 18-May & 2-Jun & 7 & 15 \\
\hline & Schubert & LG & 1-Mar & 6-Mar & 3 & 5 \\
\hline & & & 18-May & 5-Jun & 3 & 18 \\
\hline & & MG & 1-Mar & 6-Mar & 4 & 5 \\
\hline & & & 18-May & 5-Jun & 4 & 18 \\
\hline \multirow[t]{13}{*}{96} & Campbell & LG & 15-Feb & 20-Feb & 4 & 5 \\
\hline & & & 30-Apr & 9-May & 4 & 9 \\
\hline & & & 9-May & 13-May & 6 & 4 \\
\hline & & MG & 15-Feb & 20-Feb & 2 & 5 \\
\hline & & & 30-Apr & 9-May & 2 & 9 \\
\hline & Forbes & $\mathbf{L G}$ & 5-Mar & 8-Mar & 16 & 3 \\
\hline & & & 20-Nov & 2-Dec & 7 & 12 \\
\hline & & MG & 11-Mar & 13-Mar & 16 & 2 \\
\hline & & & 20-Nov & 29-Nov & 4 & 9 \\
\hline & Schubert & LG & 14-Feb & 21-Feb & 3 & 7 \\
\hline & & & 2-May & 10-May & 6 & 8 \\
\hline & & & 25-Nov & 29-Nov & 3 & 4 \\
\hline & & MG & 14-Feb & 21-Feb & 4 & 7 \\
\hline
\end{tabular}

Table. 1 Continued.

\begin{tabular}{|c|c|c|c|c|c|c|}
\hline Year & Watershed & Treatment & On & Off & Head & Days on \\
\hline \multirow[t]{12}{*}{97} & \multirow[t]{7}{*}{ Campbell } & \multirow[t]{5}{*}{ LG } & 15-Jan & 21-Jan & 4 & 6 \\
\hline & & & 16-Apr & 24-Apr & 5 & 8 \\
\hline & & & 12-May & 14-May & 7 & 2 \\
\hline & & & 15-May & 16-May & 7 & 1 \\
\hline & & & 26-May & 28-May & 1 & 2 \\
\hline & & \multirow[t]{2}{*}{ MG } & 15-Jan & 21-Jan & 2 & 6 \\
\hline & & & 16-Apr & 24-Apr & 2 & 8 \\
\hline & \multirow[t]{3}{*}{ Forbes } & \multirow[t]{2}{*}{ LG } & 16-Apr & 23-Apr & 10 & 7 \\
\hline & & & 23-Apr & 25-Apr & 12 & 2 \\
\hline & & MG & 16-Apr & 24-Apr & 6 & 8 \\
\hline & \multirow[t]{2}{*}{ Schubert } & LG & 16-Apr & 24-Apr & 6 & 8 \\
\hline & & MG & 16-Apr & 24-Apr & 6 & 8 \\
\hline
\end{tabular}

dry matter target level was attained (MG $\sim 1000 \mathrm{~kg} / \mathrm{ha} ; \mathrm{LG} \sim 1500$ $\mathrm{kg} / \mathrm{ha}$ ). To verify grazing treatment levels, upland residual dry matter was estimated annually by comparison of aboveground herbaceous biomass from clipped plots within and outside of 3 randomly located grazing exclosures per fenced treatment plot. Residual dry matter $(\mathrm{kg} / \mathrm{ha})$ levels are given in Table 2 .

Channel cross-section sampling methods were similar to those found in Harrelson et al. (1994). At each spring and each resultant creek, 2 permanent transects were established about $4 \mathrm{~m}$ apart and perpendicular to water flow. Two workers made depthto-channel bottom measurements with a surveyor's transit and graded staff at variably spaced points along each transect. Sampling points along transects were determined based on visually apparent depth transitions and ranged from $5-50 \mathrm{~cm}$ apart. Once established, points were fixed and sampled each year. Cross-sectional sampling was performed prior to fall precipitation in late August/early September for 5 years.
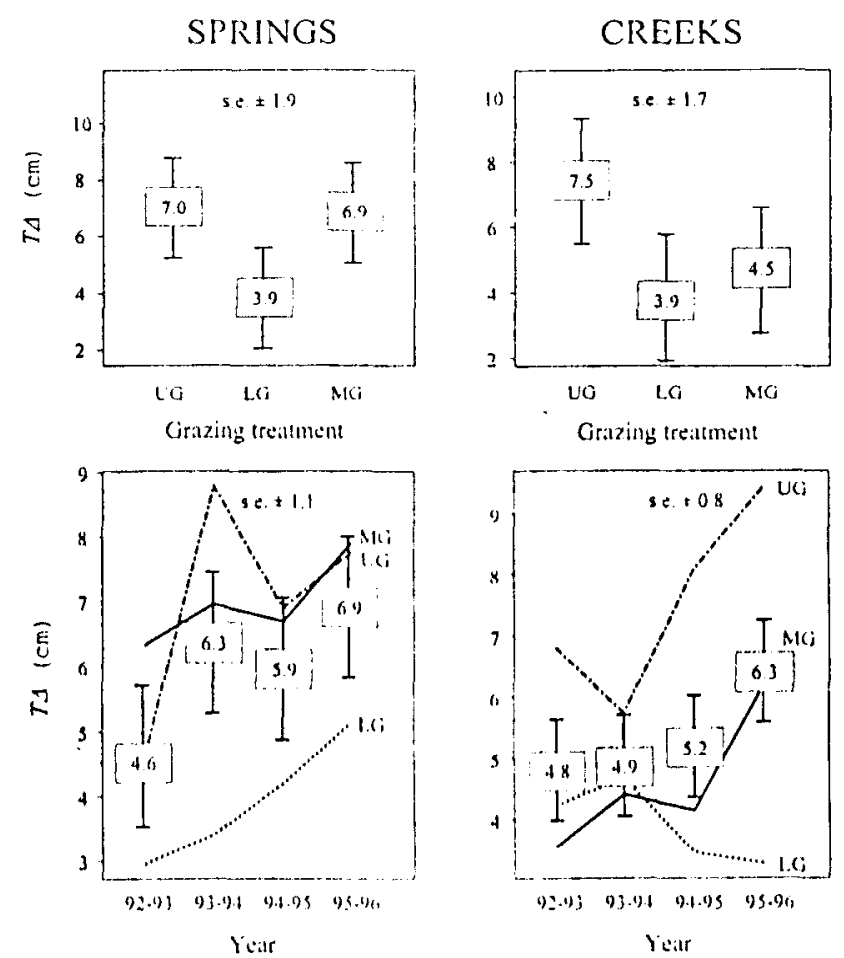

Fig. 2. Mean total change (T $\Delta$ ) estimates for springs and creeks among grazing treatment levels and over time. 
Table. 2. Annual residual dry matter estimates.

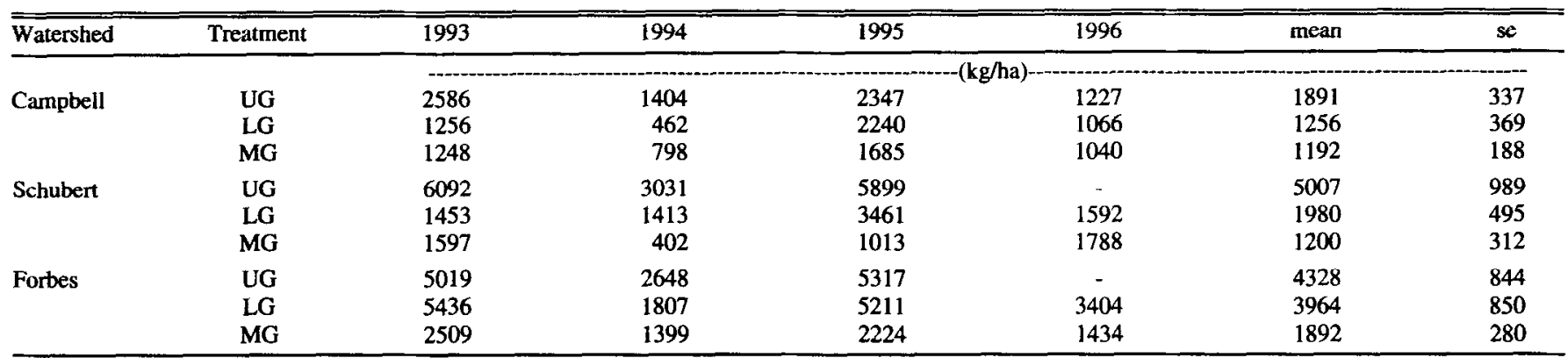

Mean total change $(T \Delta)$ per sampling unit was used to assess potential differences in channel morphology among grazing treatments and time. $T \Delta$ was defined as:

$$
T \Delta=(\mid \text { scour } \mid+ \text { fill })
$$

where, scour equals substrate removal and fill is substrate addition. Total change is a metric similar to Olson-Rutz and Marlow's (1992) absolute percent change.

Potential differences in $T \Delta$ at springs and creeks among grazing treatments were assessed with split-plot ANOVA on repeated measures. Homoscedasticity was verified for both factors but significant covariance among years indicating non-independence across factor levels rendered univariate analyses inappropriate for tests over time. Hence, MANOVA was performed on year-wise orthogonal contrasts of $T \Delta$ ensuring factor-level independence (Venables and Ripley 1994). The average Schubert-lightly grazed site value over 1992-95 replaced the 1996 missing data point.

\section{Results \& Discussion}

No significant differences in $T \Delta$ were found with split-plot ANOVA on repeated measures among grazing treatments at springs $(P=0.35)$ or creeks ( $P=0.24$ ). Likewise, MANOVA on year-wise orthogonal contrasts indicated no significant temporal changes in $T \Delta$ at springs $(P=0.23)$ or creeks $(P=0.73)$. Results are summarized graphically in Figure 2 which shows that only slightly smaller standard errors would have resulted in significant differences between both grazed and ungrazed treatment levels. It is conceivable that error variances were inflated by the somewhat variable grazing intensities applied yearly. This variability stemmed from our efforts to mimic yearlong grazing practices as nearly as possible by turning cattle into the relatively small enclosures 3 times annually. While our 5-year treatment means met targeted values, a few years found lightly grazed and moderately grazed residual dry matter target levels transposed.

A cattle trampling effect on grazed spring and creek channel morphology was and continues to be visually observed. Our methods did not detect this effect quantitatively. Means plotted over time revealed that $T \Delta$ at both springs and creeks roughly tracked annual precipitation patterns (Fig. 3). It seems clear that increased flow resulted in increased, yet not statistically significant $T \Delta$. Therefore, we examined whether there were differences in $T \Delta$ for spring/creek sites that had intermittent streams above them and those where no stream was present above the sites. We found no pattern attributable to the presence of a channel above
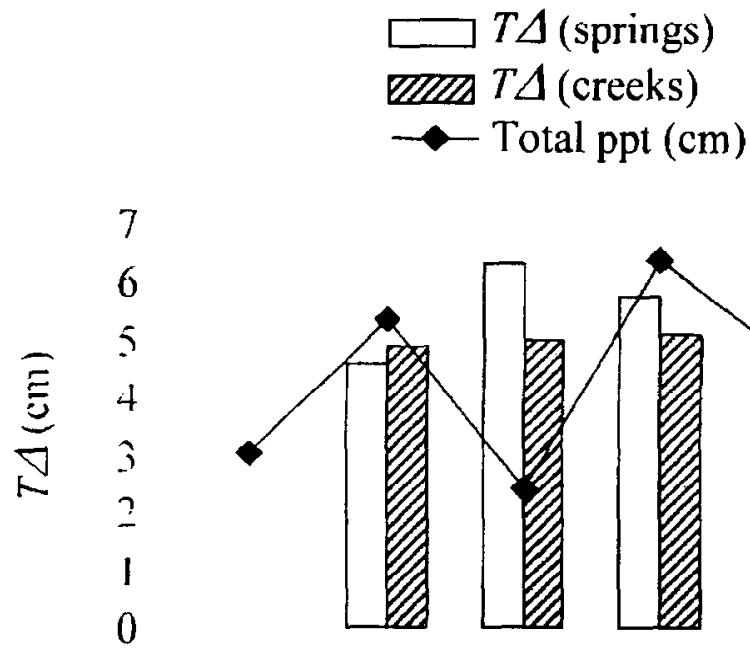

7
6
5
4
3
2
1
0

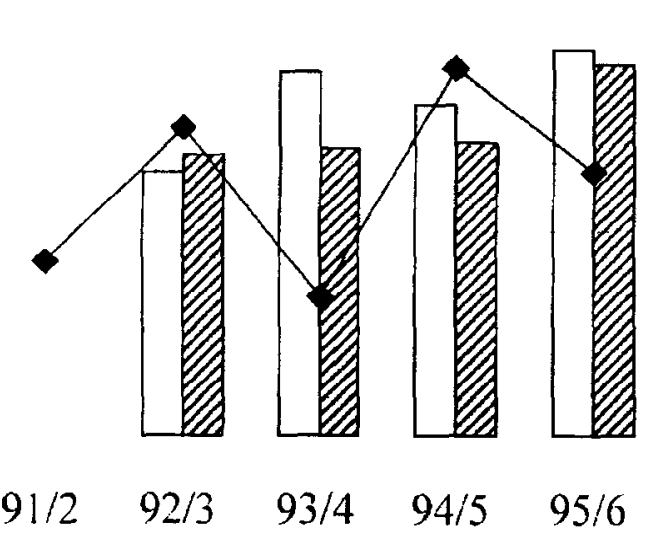

72 (30 y mean)

$46(-1 \mathrm{sd})$

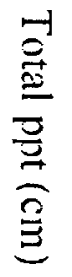

\section{0}

0

\section{Year (July-June)}

Fig. 3. Mean total change (T $\Delta$ ) and total annual rainfall (ppt) over study period. 
the site. We also looked for differences in $T \Delta$ between coarse, bedrock type springs (Type I) and fine-textured type springs (Type II) and found none. Finally, we assessed differences among grazing treatments for the 2 components of $T \Delta$ scour and fill. Again, no differences were determined.

We qualitatively observed greater $T \Delta$ at ungrazed sites for both springs and creeks. These observations are contradictory to our study's alternative hypothesis that increased grazing intensity imparts increased channel morphology change $(T \Delta)$. However, Sierra Foothill Research and Extension Center range has been historically grazed at the moderately grazed treatment level $(\sim 1000 \mathrm{~kg} / \mathrm{ha}$ residual dry matter) while lightly grazed and ungrazed represent grazing reduction and removal respectively. We believe that historic grazing intensities have likely contributed to increased sedimentation amounts and rates for each of our 9 spring systems creating relatively homogeneous substrates (Lovato Niles and Allen-Diaz; unpublished data) through which flow is impeded. We speculate that under historic grazing levels, fine sediment input and output in these systems was more or less at an equilibrium resulting in little total change $(T \Delta)$ in channel morphology. Grazing removal or reduction after $120+$ years of moderate grazing will likely result in these systems seeking alternate equilibria. If these speculations represent the true underlying processes, we predict a promotion of channel incising and narrowing at ungrazed sites in the future. Continued grazing treatment application and annual monitoring will allow us to test these liypotheses.

Permanent channel cross-section establishment is endorsed by a number of governmental and scientific sources (Platts et al. 1987) for monitoring livestock grazing impacts on riparian systems. These data are very expensive to collect in terms of field time, data entry, and data analysis. Until a better link is established between channel cross-section data collection and interpretation, and management activities such as grazing, we do not recommend this type of channel monitoring for detection of grazing intensity impacts in low-flow spring/creek systems.

\section{Literature Cited}

Bartolome, J.W. 1993. Application of the herbivore optimization theory to rangelands of the western United States. Ecol. Appl. 3:27-29.

Bartolome, J.W. 1984. Effects of grazing intensity and specialized grazing systems on vegetation productivity and composition, p. 917-926. In: Committee on developing strategies for rangeland management NAS/NRC. Westview Special Studies in Agr. Res. Westview Press, Boulder, Colo.

Buckhouse, J.C., J.M. Skovlin, and R.W. Knight. 1981. Streambank erosion and ungulate grazing relationships. J. Range Manage. 34:339-340.

Campbell, C. and B.H. Allen-Diaz. 1997. Livestock grazing and riparian habitat water quality: an examination of oak woodland springs in the Sierra Foothills of California. USDA For. Serv. Res. Paper PSWGTR-160.

Ewing, R.A., N. Tosta, R. Tuazon, L. Huntsinger, R. Marose, K. Nielson, R. Motroni, and S. Turan. 1988. California's forests and rangelands: growing conflict over changing uses. Prepared by Forest and Rangeland Resources Assessment Program (FRRAP), Calif. Dept. of Forestry and Fire Protection

Gunderson, D.R. 1968. Floodplain use related to stream morphology and fish populations. J. Wildl. Manage. 32:506-514.

Harrelson, C.C., C.L. Rawlins, and J.P. Potyondy. 1994. Stream channel reference sites: an illustrated guide to field technique. USDA For. Serv. Gen. Tech. Rep. RM-245. Fort Collins, Colo.
Herbert, F.W. and E.L. Begg, 1969. Soils of the Yuba Area California University of California, Davis, County of Yuba, Calif.

Kauffman, J.B. and W.C. Krueger. 1984. Livestock impacts on riparian ecosystems and streamside management implications...a review. J. Range Manage. 37:430-438.

Marlow, C.B., T.M. Pogacnik, and S.D. Quinsey. 1987. Streambank stability and cattle grazing in southwestern Montana. J. Soil Water Conserv. 42:291-296.

Medina, A.L. and S.C. Martin. 1988. Stream channel and vegetation changes of McKnight Creek, New Mexico (USA). Great Basin Nat. 48:373-381.

Myers, T.J. and S. Swanson. 1992. Variation of stream stability with stream type and livestock bank damage in northern Nevada. Water Res. Bull. 28:743-754.

Olson-Rutz, K.M. and C.B. Marlow. 1992. Analysis and interpretation of stream channel cross-sectional data. North Amer. J. Fish. Manage. 12:55-61.

Platts, W.S., C. Armour, G.D. Booth, M. Bryant, J.L. Bufford, P. Cuplin, S. Jensen, G.W. Lienkaemper, G.W. Minshall, S.B. Monsen, R.L. Nelson, J.R. Sedell, and J.S. Tuhy. 1987. Methods for evaluating riparian habitats with applications to management. USDA For. Serv. Gen. Tech. Rep. INT-221. Ogden, Ut.

Roath, L.R. and W.C. Krueger. 1982. Cattle grazing influence on a mountain riparian zone. J. Range Manage. 35:100-103.

Sidle, R.C. and A. Sharma. 1996. Stream channel changes associated with mining and grazing in the great basin. J. Env. Qual. 25:1111-1121.

Venables, W.N. and B.R. Ripley. 1994. Modern applied statistics with S-plus. Springer-Verlag, New York.

Williamson, R.B., R.K. Smith, and J.M. Quinn. 1992. Effects of riparian grazing and channelisation on streams in Southland, New Zealand. 1. Channel form and stability. N.Z. J. Mar. Freshwater Res. 26:241-258. 